\title{
Efficiency of cultivation technologies for spring wheat with different levels of intensity on chernozem soils of Kursk Region
}

\author{
Vladimir Lazarev ${ }^{1, *}$, and Boris Ilyin ${ }^{1}$ \\ ${ }^{1}$ Kursk Federal Agricultural Research Center, Kursk, Russia
}

\begin{abstract}
The paper presents the results of research on the efficiency of technologies for cultivating spring wheat at various levels of intensity (extensive, intensive, resource-saving) under the conditions of chernozem soils of Kursk Region. It was found that higher reserves of available moisture and nitrate nitrogen in the arable layer of the soil before sowing spring wheat were provided by technologies with moldboard plowing. Replacing plowing with subsurface methods of tillage led to a decrease in the available moisture and nitrate nitrogen reserves in the soil for all fertilizer systems. The lowest weediness of spring wheat was observed when it was cultivated using technologies with moldboard plowing - 52.3-58.3 PCs $/ \mathrm{m} 2$, depending on the fertilizer system. The replacement of plowing with subsurface and surface tillage increased the weediness of crops to 61.7 and $73.7 \mathrm{PCs} / \mathrm{m} 2$, respectively. Application of mineral fertilizers had almost no significant effect on the number of weeds in spring wheat. The highest yield of spring wheat in all the years of studies $(4,27 \mathrm{t} / \mathrm{ha})$ was obtained in the intensive cultivation technology involving plowing at $20-22 \mathrm{~cm}$, fertilization at a rate of N60P60K60, treatment of crops with pesticides based on economic threshold of harmfulness. Yield of spring wheat, cultivated by resource-saving technologies with organic-mineral system of fertilization $0.86-4.25 \mathrm{t} / \mathrm{ha}$ depending on the methods of primary tillage. Moldboard plowing of the soil against the background of the organic-mineral fertilizer system increased the yield of spring wheat by $0.18 \mathrm{t} / \mathrm{ha}$ in comparison with subsurface tillage and by $0.39 \mathrm{t} / \mathrm{ha}$ in comparison with surface tillage. However, due to higher production costs, the best economic indicators were obtained when spring wheat was cultivated using resourcesaving technologies with an organic-mineral fertilizer system and non-moldboard methods of primary tillage.
\end{abstract}

Keywords: typical chernozem, spring wheat, mineral fertilizers, organic fertilizers, green manure, biopreparations, productivity, gluten content, economic efficiency.

\section{Introduction}

The most important problem of modern agricultural production is the transition to environmentally safe and economically sound technologies for crop cultivation which allow to increase the yield and quality of products and at the same time reduce environmental pollution. This requires significant changes in the applied technologies in the direction of biologization and resource conservation, while ensuring the profitability of agricultural production $[1,2,3]$.

Modern technologies of crop cultivation are a set of practices for managing the production process in order to achieve the planned yield and product quality $[4,5]$. Through crop rotation, tillage system, fertilizers and plant protection, these technologies are linked into a unified system of agropedocenosis management. At the same time, it is important to take into account the zonal soil and climatic features, as well as the features of varietal management of cultivated varieties [6].

The development of technologies for the cultivation of crops should be carried out in accordance with their agroecological requirements and environmental influence in relation to specific agro-landscapes within this agroecological group of lands, a certain level of intensity (production and resource potential of the producer), various forms of labor organization based on the planned yield and product quality in the system of environmental restrictions of technogenesis [7].

In recent years, the area of spring wheat in the structure of the area under cereal crops of Kursk Region is in the range of 50-100 thousand hectares, or 4.8-9.7\% of the area under cereal crops, and the yield ranges from $4.04 \mathrm{t} / \mathrm{ha}$ (2018) to 5.11 t/ha (2020) [8]. At the same time, production costs for the cultivation of spring wheat increased from year to year due to the rise in the cost of fuel, machinery, chemical fertilizers and plant protection products. The greatest energy costs fall on tillage $[9.10,11]$. In this regard, a very urgent task is to increase the yield of spring wheat while reducing the cost of its production through the use of resource-saving cultivation technologies based on a rational combination of fertilizer systems with different levels of biologization and methods of primary tillage.

The purpose of the research is to determine the impact of technologies with different levels of intensity (extensive, intensive, resource-saving) on the yield, grain quality, reduction of labor and energy costs in the cultivation of spring wheat.

\footnotetext{
* Corresponding author: vla190353@yandex.ru
} 


\section{Objects and methods}

The research was carried out in the long-term stationary experiment of the Laboratory of Technologies for Field Crop Cultivation and Environmental Assessment of Lands of Kursk Federal Agricultural Research Center in 2018-2020 in the third cycle of a 9-field crop rotation with the following alternation of crops: clover 1st cut winter wheat - sugar beet - spring wheat - peas/oats winter rye - buckwheat - oats - barley+clover.

The efficiency of spring wheat cultivation was studied using technologies with different levels of intensity: extensive, intensive, resource-saving. Fertilizer systems (factor A) and primary tillage methods (factor B) were studied as intensification factors.

Experiment design: 1. Extensive technology: plowing by $20-22 \mathrm{~cm}$, without fertilizing, treatment of crops with pesticides taking into account the economic threshold of harmfulness; 2. Intensive technology: plowing by $20-22 \mathrm{~cm}$, application of mineral fertilizers at a rate of $\mathrm{N} 60 \mathrm{P} 60 \mathrm{~K} 60$, treatment of crops with pesticides taking into account the economic threshold of harmfulness; 3. Resource-saving technology 1: plowing at $20-22 \mathrm{~cm}$, application of mineral fertilizers at a rate of $30 \mathrm{P} 30 \mathrm{~K} 30$, embedding of sugar beet tops in the soil, treatment of crops with Humistim biopreparation in the tillering phase and early booting at a rate of $3 \mathrm{l} / \mathrm{ha}$, treatment of crops with pesticides taking into account the economic threshold of harmfulness; 4. Resourcesaving technology 2: subsurface tillage of $20-22 \mathrm{~cm}$, application of mineral fertilizers at a rate of N30P30K30, embedding of sugar beet tops in the soil, treatment of crops with Humistim biopreparation in the tillering phase and early booting at a rate of $3 \mathrm{l} / \mathrm{ha}$, treatment of crops with pesticides taking into account the economic threshold of harmfulness; 5. Resourcesaving technology 3: surface tillage of $8-10 \mathrm{~cm}$, application of mineral fertilizers at a rate of N30P30K30, embedding of sugar beet tops in the soil, treatment of crops with Humistim biopreparation in the tillering phase and early booting at a rate of $31 / \mathrm{ha}$, treatment of crops with pesticides taking into account the economic threshold of harmfulness.

The soil of the experimental site is represented by chernozem of a typical heavy-loamy granulometric composition. The content of humus in the arable layer is $6.1 \%$, of mobile phosphorus (according to Chirikov method) $15.6 \mathrm{mg} / 100 \mathrm{~g}$ of soil, exchangeable potassium (according to Maslova method) $11.3 \mathrm{mg} / 100 \mathrm{~g}$ of soil. The reaction of the soil medium is neutral $(\mathrm{pH} 6.5)$. The tyer in the experiment is 3 -fold. The location of the plots is systematic, the area of the experimental plot is 100 $\mathrm{m} 2$. Spring wheat variety is Daria. The seeding rate is 5 million germinating seeds per 1 ha.

Harvesting was carried out by a self-propelled harvester "Sampo-500" by direct harvesting. The crop was recalculated for $100 \%$ purity and $14 \%$ moisture content in the grain. The gluten content (GOST 544782011), natural grain weight (GOST 10840-2017), and weight of 1000 grains (GOST 10842-89) were determined in the samples. The experimental data were processed by the method of dispersion analysis.
Meteorological conditions in the years of the experiment were typical for Kursk Region. The growing season of spring wheat in 2018 was characterized by cool and humid weather: the average daily temperature in April-July was $0.2^{\circ} \mathrm{C}$ lower than the long-term average, with precipitation totaling $272.5 \mathrm{~mm}$, or 126.7 $\%$ of the norm. The average daily temperature of the growing season of spring wheat in 2019 and 2020 was by $1.8-0.7^{\circ} \mathrm{C}$ higher than the long-term average $\left(14.2^{\circ} \mathrm{C}\right)$, and the amount of precipitation was 197.5 $213.6 \mathrm{~mm}$, or $91.9-99.3 \%$ of the average long-term amount $(215.0 \mathrm{~mm})$.

\section{Results and Discussion}

Technologies of cultivation of spring wheat with different levels of intensity had a significant impact on the content of available moisture and nitrate nitrogen in the soil, the weediness of crops, the yield and quality of grain.

Table 1. Influence of cultivation technologies on available moisture reserves in the topsoil before sowing spring wheat (2018-2020)

\begin{tabular}{|l|l|l|}
\hline \multicolumn{1}{|c|}{ Variants } & $\begin{array}{l}\text { Available } \\
\text { moisture } \\
\text { reserves, } \\
\mathrm{mm}\end{array}$ & $\begin{array}{l}+/- \\
\text { the } \\
\text { control }\end{array}$ \\
\hline $\begin{array}{l}\text { 1.Extensive technology: } \\
\text { unfertilized, plowing }\end{array}$ & 23.7 & \\
\hline $\begin{array}{l}\text { 2.Intensive technology: } \\
\text { 100 \% min., } \mathrm{N}_{60} \mathrm{P}_{60} \mathrm{~K}_{60} . \\
\text { plowing }\end{array}$ & 24.4 & +0.7 \\
\hline $\begin{array}{l}\text { 3.Resource-saving } \\
\text { technology 1: 50\% org. } \\
\text { 50\% min. sugar beet tops } \\
+ \text { Humistim }+\mathrm{N}_{30} \mathrm{P}_{30} \mathrm{~K}_{30}, \\
\text { plowing }\end{array}$ & 24.7 & $+1.0-$ \\
\hline $\begin{array}{l}\text { 4. Resource-saving } \\
\text { technology 2: 50\% org. } \\
50 \% \text { min., sugar beet tops } \\
+ \text { Humistim }+\mathrm{N}_{30} \mathrm{P}_{30} \mathrm{~K}_{30}, \\
\text { subsurface tillage }\end{array}$ & 22.1 & -1.6 \\
\hline $\begin{array}{l}\text { 5. Resource-saving } \\
\text { technology 3: } 50 \% \text { org. } \\
50 \% \text { min. sugar beet tops } \\
+ \text { Humistim }+\mathrm{N}_{30} \mathrm{P}_{30} \mathrm{~K}_{30}, \\
\text { surface tillage }\end{array}$ & 21.7 & \\
\hline
\end{tabular}

Observations of the soil moisture regime under spring wheat during 2018-2020 showed that the moisture availability of the sown crops was more dependent on the methods of primary tillage, meteorological conditions of the year, and, to a lesser extent, on a fertilizer system.

Thus, higher reserves of available moisture in the topsoil before sowing spring wheat were observed when 
it was sown after plowing $23.7-24.7 \mathrm{~mm}$ deep. Replacing plowing with subsurface tillage led to a decrease in the reserves of available moisture in the topsoil by $2.6 \mathrm{~mm}$, and by $3.0 \mathrm{~mm}$ with surface tillage.

The effect of fertilizer systems on the available moisture reserves in the arable layer of the topsoil before sowing spring wheat was less significant. Thus, when cultivating spring wheat by intensive technology using a mineral fertilizer system, the reserves of available moisture in the topsoil increased by $0.7 \mathrm{~mm}$, and by 1.0 $\mathrm{mm}$ when using an organic-mineral system in comparison with the extensive cultivation technology, where fertilizers were not used.

Higher reserves of nitrate nitrogen $(38.3-38.5 \mathrm{~kg} / \mathrm{ha})$ in the soil layer of $0-40 \mathrm{~cm}$ before sowing spring wheat were noted in the variants where it was cultivated using intensive technology, which included plowing by $20-22$ $\mathrm{cm}$, applying mineral fertilizers at a rate of N60P60K60, treating crops with pesticides taking into account the economic threshold of harmfulness, as well as resourcesaving technology (plowing by $20-22 \mathrm{~cm}$, embedding sugar beet tops, applying mineral fertilizers at a rate of N30P30K30, treatment of crops with Humistim biopreparation in the tillering phase and early booting at a rate of $31 /$ ha, treatment of crops with pesticides, taking into account the economic threshold of harmfulness).

When cultivating spring wheat using resourcesaving technologies with non-moldboard methods of primary tillage (subsurface tillage to a depth of 20-22 $\mathrm{cm}$ and surface one to a depth of $10-12 \mathrm{~cm}$ ), the reserves of nitrate nitrogen before sowing spring wheat decreased up to $38.0-37.0 \mathrm{~kg} / \mathrm{ha}$, respectively.

By the time of spring wheat earing, the reserves of nitrate nitrogen in the soil layer of $0-40 \mathrm{~cm}$ increased to $64.9-72.4 \mathrm{~kg} / \mathrm{ha}$, but the regularity in the accumulation of nitrate nitrogen according to the experimental variants that developed before sowing spring wheat remained.

Before harvesting spring wheat, the nitrate nitrogen reserves were minimal (11.3-13.2 kg/ha), but there was practically no difference in the variants, that is, the nitrate nitrogen reserves were leveled by the time of harvesting spring wheat cultivated using various technologies.

Table 2. Influence of cultivation technologies on nitrate nitrogen reserves under spring wheat (2018-2020)

\begin{tabular}{|l|c|c|c|}
\hline \multirow{2}{*}{ Variants } & \multicolumn{3}{|c|}{ Nitrate Nitrogen Reserves } \\
\cline { 2 - 4 } & $\begin{array}{l}\text { before } \\
\text { sowing }\end{array}$ & earing & $\begin{array}{c}\text { before } \\
\text { harvesting }\end{array}$ \\
\hline $\begin{array}{l}\text { 1.Extensive } \\
\text { technology: } \\
\text { unfertilized, } \\
\text { plowing }\end{array}$ & 27.0 & 64.9 & 11.3 \\
\hline $\begin{array}{l}\text { 2.Intensive } \\
\text { technology: } 100 \\
\% \text { min., } \\
\begin{array}{l}\mathrm{N}_{60} \mathrm{P}_{60} \mathrm{~K}_{60} . \\
\text { plowing }\end{array}\end{array}$ & 38.3 & 72.4 & 12.2 \\
\hline
\end{tabular}

\begin{tabular}{|l|l|l|l|}
\hline $\begin{array}{l}\text { 3.Resource- } \\
\text { saving }\end{array}$ & & & \\
technology 1: & & & \\
$\begin{array}{l}50 \% \text { org. } 50 \% \\
\text { min. sugar beet }\end{array}$ & 38.5 & 71.6 & 13.2 \\
tops + Humistim & & & \\
$+\mathrm{N}_{30} \mathrm{P}_{30} \mathrm{~K}_{30}$. & & & \\
plowing & & & \\
\hline $\begin{array}{l}\text { 4. Resource- } \\
\text { saving }\end{array}$ & & & \\
technology 2: & & & \\
$\begin{array}{l}50 \% \text { org. } 50 \% \\
\text { min., sugar beet }\end{array}$ & 38.0 & 70.5 & 13.1 \\
tops + Humistim & & & \\
$+\mathrm{N}_{30} \mathrm{P}_{30} \mathrm{~K}_{30}$, & & & \\
subsurface tillage & & & \\
\hline $\begin{array}{l}5 . \text { Resource- } \\
\text { saving }\end{array}$ & & & \\
technology 3: & & & \\
$\begin{array}{l}50 \% \text { org. } 50 \% \\
\text { min. sugar beet }\end{array}$ & 37.0 & 69.7 & 12.8 \\
tops + Humistim & & & \\
$+\mathrm{N}_{30} \mathrm{P}_{30} \mathrm{~K}_{30}$, & & & \\
surface tillage & & & \\
\hline
\end{tabular}

Technologies of cultivating spring wheat with different levels of intensity had a significant impact on the weed infestation of crops.

The lowest weediness of spring wheat crops 48.0$54.0 \mathrm{pcs} / \mathrm{m} 2$ was observed when it was cultivated using technologies with moldboard tillage, depending on the fertilizer system.

Technologies of cultivating spring wheat with different levels of intensity had a significant impact on the weed infestation of crops.

The lowest weediness of spring wheat crops 48.0$54.0 \mathrm{pcs} / \mathrm{m} 2$ was observed when it was cultivated using technologies with moldboard tillage, depending on the fertilizer system.

The replacement of moldboard tillage with subsurface and surface tillage led to an increase in the weediness of crops. The number of weeds in spring wheat, when cultivated with subsurface tillage, was 57.3 $\mathrm{pcs} / \mathrm{m} 2$, and $70.7 \mathrm{pcs} / \mathrm{m} 2$ with surface tillage. The application of mineral fertilizers had almost no significant effect on the number of weeds in spring wheat.

Table 3. Influence of cultivation technologieson spring wheat weediness $(2018-2020)$

\begin{tabular}{|c|c|c|}
\hline \multirow{2}{*}{ Variants } & \multicolumn{2}{|c|}{$\begin{array}{l}\text { Weediness of Spring } \\
\text { Wheat in the Tillering } \\
\text { Period }\end{array}$} \\
\cline { 2 - 3 } & $\mathrm{pcs} / \mathrm{m}^{2}$ & $\mathrm{~g} / \mathrm{m}^{2}$ \\
\hline $\begin{array}{c}\text { 1.Extensive } \\
\text { technology: unfertilized, } \\
\text { plowing }\end{array}$ & 48.0 & 55.1 \\
\hline $\begin{array}{c}\text { 2.Intensive } \\
\text { technology: 100\% min., } \\
\mathrm{N}_{60} \mathrm{P}_{60} \mathrm{~K}_{60} \text { plowing }\end{array}$ & 50.6 & 67.0 \\
$\begin{array}{c}\text { 3.Resource-saving } \\
\text { technology 1: 50\% org. }\end{array}$ & 54.0 & 61.7 \\
\hline
\end{tabular}




\begin{tabular}{|c|c|c|}
\hline $\begin{array}{l}50 \% \text { min. sugar beet tops } \\
+ \text { Humistim }+\mathrm{N}_{30} \mathrm{P}_{30} \mathrm{~K}_{30} \text {. } \\
\text { plowing }\end{array}$ & & \\
\hline $\begin{array}{l}\text { 4. Resource-saving } \\
\text { technology 2: } 50 \% \text { org. } \\
50 \% \text { min., sugar beet tops } \\
+ \text { Humistim }+\mathrm{N}_{30} \mathrm{P}_{30} \mathrm{~K}_{30} \text {, } \\
\text { subsurface tillage }\end{array}$ & 57.3 & 68.7 \\
\hline $\begin{array}{l}\text { 5. Resource-saving } \\
\text { technology 3: } 50 \% \text { org. } \\
50 \% \text { min. sugar beet tops } \\
+ \text { Humistim }+\mathrm{N}_{30} \mathrm{P}_{30} \mathrm{~K}_{30} \text {, } \\
\text { surface tillage }\end{array}$ & 70.7 & 80.8 \\
\hline
\end{tabular}

The highest yield of spring wheat in all the years of research (4.27 t/ha) was obtained when it was cultivated using intensive technology, which included plowing 20$22 \mathrm{~cm}$, applying mineral fertilizers at a rate of N60P60K60, treating crops with pesticides, taking into account the economic threshold of harmfulness (Table 4).

The cultivation of spring wheat by resource-saving technology with moldboard tillage, organic-mineral fertilizer system, treatment of crops with bio-organic fertilizer Humistim in the tillering phase and early booting at a rate of $31 / \mathrm{ha}$ and herbicides, taking into account the economic threshold of harmfulness, allowed to obtain almost equal productivity (4.26 t/ha) as when it was cultivated by intensive technology.

The yield of spring wheat cultivated according to resource-saving technologies with an organic-mineral fertilizer system and non-moldboard tillage methods (subsurface, surface tillage) was 4.08-3.87 t/ha, or 0.18$0.39 \mathrm{t} / \mathrm{ha}$ lower than when it was cultivated by plowing.

Table 4. Influence of cultivation technologies on spring wheat yield (2018-2020).

\begin{tabular}{|c|c|c|c|}
\hline \multirow[b]{2}{*}{ Variants } & \multirow[b]{2}{*}{$\begin{array}{l}\text { Yield, } \\
\text { t/ha }\end{array}$} & \multicolumn{2}{|c|}{ Increase, $t / h a$} \\
\hline & & $\begin{array}{l}\text { due to } \\
\text { fertilezer }\end{array}$ & $\begin{array}{l}\text { due to } \\
\text { tillage } \\
\text { method }\end{array}$ \\
\hline $\begin{array}{l}\text { 1.Extensive } \\
\text { technology: } \\
\text { unfertilized, plowing }\end{array}$ & 3.14 & - & \\
\hline $\begin{array}{l}\text { 2.Intensive } \\
\text { technology: } 100 \% \\
\text { min., } \quad \mathrm{N}_{60} \mathrm{P}_{60} \mathrm{~K}_{60} \\
\text { plowing }\end{array}$ & 4.27 & +1.13 & \\
\hline $\begin{array}{l}\text { 3.Resource-saving } \\
\text { technology } 1: \quad 50 \% \\
\text { org. } 50 \% \text { min. sugar } \\
\text { beet tops }+ \text { Humistim } \\
+\mathrm{N}_{30} \mathrm{P}_{30} \mathrm{~K}_{30} \text {. plowing }\end{array}$ & 4.26 & +1.12 & - \\
\hline $\begin{array}{l}4 . \text { Resource-saving } \\
\text { technology } 2: \quad 50 \% \\
\text { org. } 50 \% \text { min., sugar } \\
\text { beet tops }+ \text { Humistim } \\
+\quad \mathrm{N}_{30} \mathrm{P}_{30} \mathrm{~K}_{30} \text {, } \\
\text { subsurface tillage }\end{array}$ & 4.08 & +0.94 & -0.18 \\
\hline
\end{tabular}

\begin{tabular}{|l|l|l|l|}
\hline $\begin{array}{l}5 . \quad \text { Resource-saving } \\
\text { technology 3: 50\% } \\
\text { org. } 50 \% \text { min. sugar } \\
\text { beet tops }+ \text { Humistim }\end{array}$ & 3.87 & +0.73 & -0.39 \\
$+\mathrm{N}_{30} \mathrm{P}_{30} \mathrm{~K}_{30}$, surface & & & \\
tillage & & & \\
\hline $\mathrm{LSD}_{05}$ by factor $\mathrm{A}$ & 0.22 & \\
$\mathrm{LSD}_{05}$ by factor $\mathrm{B}$ & 0.12 & \\
\hline
\end{tabular}

Various technologies of cultivation of spring wheat had a significant impact on the quality of grain.

A higher content of raw gluten in the grain of spring wheat was obtained when it was cultivated using intensive technology with a mineral fertilizer system $22.3 \%$. In the control version (extensive technology), the content of raw gluten was $20.2 \%$. When cultivating spring wheat using resource-saving technologies with an organic-mineral fertilizer system, the content of raw gluten in the grain was $22.0 \%$ when cultivating it by plowing; $21.5 \%$ by subsurface tillage and $20.3 \%$ by surface tillage (Table 5).

The best economic indicators were provided by the cultivation of spring wheat using resource-saving technologies, which included an organic-mineral fertilizer system and non-moldboard methods of primary tillage. Thus, the value of the conditional net income in the variant with subsurface tillage was 28,356 rubles/ha, the cost of 1 ton of grain-5,050.00 rubles, the level of profitability - $137.6 \%$, and in the variant with surface tillage-26,458 rubles/ ha, 5,163.31 rubles / $\mathrm{t}$, and $132.2 \%$, respectively.

Table 5. Influence of cultivation technologies on the content of raw gluten in spring wheat grain (20182020)

\begin{tabular}{|c|c|c|c|}
\hline \multirow[b]{2}{*}{ Variants } & \multirow[b]{2}{*}{$\begin{array}{l}\text { Gluten } \\
\text { Content } \\
\%\end{array}$} & \multicolumn{2}{|c|}{ Increase, \% } \\
\hline & & $\begin{array}{l}\text { due to } \\
\text { fertili } \\
\text { zer }\end{array}$ & $\begin{array}{l}\text { due to } \\
\text { tillage } \\
\text { method }\end{array}$ \\
\hline $\begin{array}{l}\text { 1.Extensive technology: } \\
\text { unfertilized, plowing }\end{array}$ & 20.2 & - & \\
\hline $\begin{array}{l}\text { 2.Intensive } \\
100 \% \text { min., } \mathrm{N}_{60} \mathrm{P}_{60} \mathrm{~K}_{60} \\
\text { plowing }\end{array}$ & 22.3 & +2.1 & - \\
\hline $\begin{array}{l}\text { 3.Resource-saving } \\
\text { technology } 1: \quad 50 \% \text { org. } \\
50 \% \text { min. sugar beet tops }+ \\
\begin{array}{l}\text { Humistim }+\mathrm{N}_{30} \mathrm{P}_{30} \mathrm{~K}_{30} . \\
\text { plowing }\end{array}\end{array}$ & 22.0 & +1.8 & - \\
\hline $\begin{array}{l}\text { 4.Resource-saving } \\
\text { technology } 2: 50 \% \text { org. } \\
50 \% \text { min., sugar beet tops } \\
+ \text { Humistim }+\mathrm{N}_{30} \mathrm{P}_{30} \mathrm{~K}_{30} \text {, } \\
\text { subsurface tillage }\end{array}$ & 21.5 & +1.3 & -0.5 \\
\hline $\begin{array}{l}\text { 5.Resource-saving } \\
\text { technology 3: } 50 \% \text { org. } \\
50 \% \text { min. sugar beet tops }+ \\
\text { Humistim }+\mathrm{N}_{30} \mathrm{P}_{30} \mathrm{~K}_{30}, \\
\text { surface tillage }\end{array}$ & 20.3 & +0.1 & -1.7 \\
\hline $\begin{array}{l}\mathrm{LSD}_{05} \text { by factor } \mathrm{A} \\
\mathrm{LSD}_{05} \text { by factor } \mathrm{B}\end{array}$ & & $\begin{array}{l}0.6 \\
0.4 \\
\end{array}$ & \\
\hline
\end{tabular}


Replacing non-moldboard methods of tillage with plowing, although provided a higher cost of gross output $(51,120$ rubles/ha), however, due to higher production costs $(22,452$ rubles/ha), it increased the cost of 1 ton of grain by 107.11-221.42 rubles, and led to a decrease in the level of profitability by $4.7-9.9 \%$.

\section{Conclusion}

Thus, the result of the research was a comprehensive agro-economic assessment of various technologies of spring wheat cultivation, which combine the principles of increasing the productivity of arable land, environmental protection and resource conservation. It was found that the highest yield of spring wheat in all the years of the research $(4.27 \mathrm{t} / \mathrm{ha})$ was provided by its cultivation using intensive technology, which included plowing 20-22 cm, applying mineral fertilizers at a rate of N60P60K60, and treating crops with pesticides, taking into account the economic threshold of harmfulness. The yield of spring wheat cultivated according to resource-saving technologies with an organic-mineral fertilizer system and non-moldboard methods of primary tillage (subsurface, surface tillage), although it led to a decrease in the yield of spring wheat by $0.18-0.39 \mathrm{t} / \mathrm{ha}$, however, due to a decrease in direct production costs (by $8.2-9.6 \%$ ), it provided better economic indicators.

The work was carried out within the framework of the state task of Kursk Federal Agricultural Research Center on topic No. 0632-2019-0010 "To develop scientifically substantiated parameters for the designing of farming systems and agricultural technologies of a new generation in order to produce a given quantity and quality of agricultural products, preserve and reproduce soil fertility".

\section{References}

1. V. I. Kiryushin, Euras. Soil Sci.. 7 871-879 (2020)

2. P.A. Chekmarev, S. V. Lukin, Zemledelie 8 3-6 (2014)

3. A.V. Gostev Efficiency of Technologies of Different Intensity Levels in the Cultivation of Grain Crops on Chernozem Soils of the Central Chernozem Region, Kursk: FGBNU VNIIZiZPE (2017)

4. Technologies of the XXI Century in the AgroIndustrial Complex of Russia, Moscow, Rosselkhosakademia (2011)

5. N. Z. Milashchenko, S. V. Trushkin., 3, 50-52 (2011).

6. I. G. Pykhtin., A.V, Gostev., N. B. Nitchenko., V. A. Plotnikov Zemledelie 6 16-19 (2016)

7. A. A. Zhuchenko, Ecological genetics of cultivated plants and problems of the agrosphere (theory and practice) 1 (2004)

8. V. I. Lazarev, Zh. N. Minchenko, A. Ya. Bashkatov. Theor. \& Appl. Ecol. 3 153-159 (2020)

9. G.N. Cherkasov et al. Theoretical foundations of the formation of agrotechnological policy for the application of zero and surface tillage for grain crops in modernization of agriculture, Kursk: GNU VNIIZiZPE (2012)

10. V.P. Belobrov, S.A. Yudin, N.V. Yaroslavtseva, A.V. Yudin, V.K. Dridiger, R.S. Stukalov, N.N. Klyuev, I.V. Zamotaev, N.R. Ermolaev, A.L. Ivanov, V.A. Kholodov Euras. Soil Sci. 7 880-889 (2020)

11. I. M. Mikhailenko, Theoretical foundations and technical implementation of managing technologies, St. Petersburg, SPbSTU (2017) 